\title{
Are Family Members Expropriated-Monitoring Shareholders? Non-Linear Evidence from the Saudi Arabia
}

\author{
(Adakah Ahli Keluarga Merupakan Pemegang Saham Perampas-Pemantau? Bukti Bukan Linear \\ dari Arab Saudi)
}

\author{
Shehabaddin Abdullah A. Al-Dubai \\ Ku Nor Izah Ku Ismail \\ Noor Afza Amran \\ (School of Accountancy, Universiti Utara Malaysia)
}

\begin{abstract}
As family businesses grow worldwide, the significant role of family shareholders on firm value becomes questionable. This study seeks to address this issue and provides new evidence on the non-linearity of family ownership-firm value relationship, based on 375 firm-year observations of 75 public listed companies in Saudi Arabia over five consecutive years (2007-2011). Interestingly, we provided evidence that the behavior of the Saudi families is changeable between expropriation and monitoring during the life of the business depending on the percentage of family ownership. We found sufficient evidence that the turning point occurs at the 28\% family ownership. This confirmed the expropriated-monitoring behavior of family shareholders in their businesses. These results were robust with respect to different family definitions and analyses. Our findings suggested that investors should not undervalue Saudi family firms due to family ownership per se. At a certain degree of ownership, the benefits of Saudi family monitoring actually exceed the costs. The results suggested that there may be a need to encourage policy makers in Saudi Arabia to impose the full disclosure of firms' ownership information, including the percentage of ownership and the identity of owners.
\end{abstract}

Keywords: Family business; family ownership; firm value; non-linearity; Saudi Arabia

ABSTRAK

Pertumbuhan perniagaan keluarga yang pesat berkembang di seluruh dunia telah memberi kesan signifikan kepada persoalan pemegang saham keluarga ke atas nilai firma. Oleh itu, kajian ini ingin menjawab persoalan ini dan menunjukkan bukti baru hubungan ketidaklinearan pemilikan keluarga dengan hubungan nilai firma berdasarkan pemerhatian ke atas 375 firma dari 75 Syarikat Tersenarai Awam di Arab Saudi bagi lima tahun berturut-turut (2007-2011). Apa yang menarik, kajian ini mendapati tingkah laku keluarga Arab berubah-ubah sepanjang hayat perniagaan, bergantung kepada peratus pemilikan keluarga. Kajian mendapati bahawa arah perubahan bertukar pada $28 \%$ pemilikan. Ini membuktikan tingkah laku merampas-memantau di kalangan pemegang saham keluarga di dalam perniagaan masing-masing. Keputusan ini adalah mantap kerana beberapa definisi keluarga yang berbeza telah digunakan dan analisis telah dijalankan di dalam kajian ini. Penemuan kajian ini mencadangkan pelabur tidak perlu menilai rendah terhadap firma keluarga Arab Saudi dengan hanya melihat kepada pemilikan keluarga sahaja. Pada tahap pemilikan yang tertentu, manfaat pemantauan pemilikan keluarga Arab adalah melebihi kos. Keputusan menyarankan adalah perlu untuk menggalakkan penggubal polisi di Arab Saudi mengenakan pendedahan penuh ke atas firma berkaitan maklumat pemilikan termasuklah peratus pegangan pemilikan dan identiti pemilik.

Kata kunci: Perniagaan keluarga; pemilikan keluarga; nilai firma; ketidaklinearan; rampasan; pemantauan; Arab Saudi

\section{INTRODUCTION}

Jensen and Meckling (1976) offered several techniques of corporate control affecting the achievement of organizational objectives; and ownership structure is one of them. Ownership structure is crucial, particularly for firms owned by a family or by a group of families. This is because the firms' objectives are interrelated with those of the family and owners who protect the family agenda by maintaining the independence of their firms. This leads to the irregular alignment of the owner's interest (which focuses on family relationship) and the manager's interest (which focuses on both profitability and competitive advantage), leading to the possibility of agency problems (Villalonga \& Amit 2006). In other words, maintaining ownership and management in family hands may reduce the conflict of interest and agency costs, which invariably lead to the maximisation of shareholders' wealth (Seifert, Gonenct \& Wright 2005), or what is known as the convergence-of-interest or monitoring hypothesis (De Miguel, Pindado \& De la Torre 2004; Pindado \& Torre 2006). This suggests that firm performance increases as family ownership grows. 
In contrast, Pindado and Torre (2006) stated that dominant ownership by family members may not always help in maximising firm value and monitoring of managers. However, there is a great possibility of family entrenchment. For example, family owners who hold a majority of the voting shares may have personal interests in the firm and use their power to take advantage of the resources and appropriate them to other companies owned by them; hence, expropriating the rights of the minority shareholders (Claessens, Djankov \& Lang 2000; La Porta, Lopez-de-Silanes \& Shleifer 1999; Schulze, Lubatkin, Dino \& Buchholtz 2001; Villalonga \& Amit 2006). Additionally, selling assets or products of a company to selected family members at an unfair price, offering high positions to incompetent relatives and paying excessive compensation are among good examples of minority expropriation (Abdullah, Shah, Iqbal \& Gohar 2011). Such scenarios support the entrenchment behaviour of family controlling shareholders.

Thus, this study aims to contribute to the existing literature by providing an answer to the questionable role of family on firm performance, and whether it is permanent or changeable (shown by non-linear relationship). This study will enrich existing knowledge and it is hoped that the generalisability of the findings can be further improved by providing new evidence that can confirm the changeable effect of family ownership between expropriation and monitoring on firms' value. Data were extracted from 75 non-financial public firms listed on the Saudi Stock Exchange (known as Tadawul) in Saudi Arabia for the period from 2007 to 2011 (375 firm-year observations). The independent variable used in the analysis is the percentage of family ownership and its quadratic term. The dependent variable was firm performance, measured by Market-to-Book Value (MBV) ratio. Firm debt, firm age, firm size and industry sectors were included as control variables.

\section{LITERATURE REVIEW AND HYPOTHESIS DEVELOPMENT}

\section{NON-LINEARITY OF FAMILY OWNERSHIP-FIRM PERFORMANCE}

Linear and non-linear relationships between family ownership and firm performance have been confirmed in the preceding literature from all over the world. Studies that provide evidence on the relationship between the two variables are many (e.g., Al-Dubai, Ku Ismail \& Amran 2014b; Amran \& Ahmad 2010; Anderson \& Reeb 2003; Barontini \& Caprio 2006; Ben-Amar \& Andre 2006; Lee 2006; Maury 2006; Saito 2008). For example, Anderson and Reeb (2003) found a positive relationship between family ownership and firm performance in the U.S., a developed country. Likewise, in the context of developing countries, Al-Dubai et al. (2014b) and Amran and Ahmad (2010) found that family ownership positively affects firm performance of public listed companies in Saudi Arabia and Malaysia, respectively. Although limited research is available on non-linearity of the aforementioned relationship (e.g., Anderson \& Reeb 2003; De Miguel et al. 2004; Kowalewski, Talavera \& Stetsyuk 2010; Maury 2006; Morck, Shleifer \& Vishny 1988), no empirical evidence has been found in the context of the Arabic region, at least, to the best of the authors' knowledge.

Linear relationship between two variables may happen in two specific patterns: positive and negative. A positive relationship means that the two examined variables ' $A$ ' and ' $B$ ' move in the same direction, which means when variable ' $A$ ' increases, variable ' $B$ ' also increases; while a negative relationship moves in the opposite direction. Clearly, when variable ' $A$ ' is negatively associated with variable ' $\mathrm{B}$,' an increase in variable ' $\mathrm{A}$ ' will cause a decrease in variable ' $B$,' and vice versa. However, a non-linear relationship is a special case and takes several forms (e.g., U-shaped, inverted U-shaped \& $\mathrm{N}$-shaped). U-shaped and inverted U-shaped relationships are two types of what is called Quadratic-relationship with a single breakpoint as can be seen from Figure 1 (A and B). However, in order to test for the existence of U-shaped or inverted U-shaped relationships, the researcher is required to include the quadratic term (therefore, it is called quadratic-relationship) of the related independent variable into the regression model (De Miguel et al. 2004). The relationship exists when the coefficient of the quadratic term is statistically significant. N-shaped (Cubic) relationship is another kind of non-linearity which is depicted graphically with maximum (FO1) and minimum (FO2) breakpoints (see Figure 1: C). To test such relationship, a cube along with a quadratic term must be included into the regression model and when the coefficient of the cubic term is significant, the relationship is confirmed. However, the focus of this study is on quadratic-relationship and our aim is to confirm its existence.

When family ownership is associated with firm performance in a U-shaped pattern, it means that the families behave changeably inside the firms; which results in different outcomes at different points of ownership. Initially, an increase in family ownership facilitates the expropriation behaviour of families towards the minority shareholders; which results in destructive performance. However, after a critical level of family ownership, firm performance improves as family ownership increases (monitoring stage). However, in case of the inverted U-shaped relationship, family owners have more incentives to pursue their monitoring behaviour; and in turn, support firm performance when their shares are low. However, when they become more dominant, they are more likely to expropriate the minority shareholders to achieve objectives different from those of the organisation or maintain a high influence on the management (Anderson \& Reeb 2003).

Arguments in the literature imply that family ownership affects firm performance in either a positive 

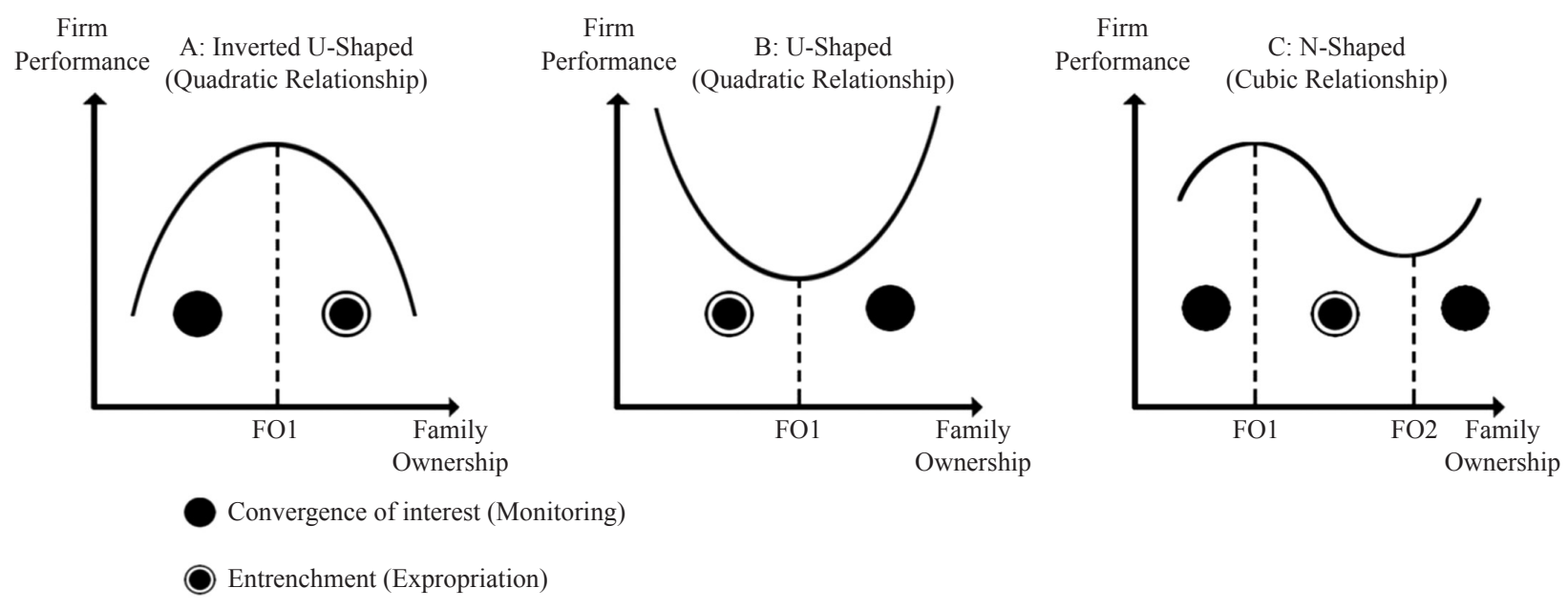

FIGURE 1. Non-linear relationship forms

or a negative manner (Sciascia \& Mazzola 2008). This argument is expected, particularly in light of the expropriating and monitoring behaviour of the dominant family block holders (Arosa, Iturralde \& Maseda 2010). Corbetta and Salvato (2004) argued that ownership concentration in the hands of a family or group of families diminishes agency problems that may exist between dominant and minority shareholders. Kula (2005) added to this contention by stating that a high level of family ownership concentration assists in the prevention of agency problems.

According to Corbetta and Salvato (2004), agency problems do occur between family and minority shareholders although the conflict of interest is low if not negligible in firms that are privately held. However, it tends to be high in the case of publicly listed family firms or in firms wherein external entities have a hand in the ownership. However, while the expropriation of resources by majority shareholders has been known to occur in public listed companies (Miller, Le Breton-Miller, Lester \& Cannella 2007), it has also been found in small and medium non-listed companies (Arosa et al. 2010).

Empirical research has found a non-linear relationship between ownership concentration and firm performance in publicly listed family firms (Anderson \& Reeb 2003; Maury 2006; Morck et al. 1988), which was later confirmed by Kowalewski et al. (2010), using return on assets (ROA) and return on equity (ROE) as proxies of firm performance. Morck et al. (1988) investigated the effect of managerial ownership on Tobin's Q and revealed that the link between the two factors is non-linear, indicating that an increase in Tobin's Q occurs when management works in the owner's best interests. However, a decrease in market value indicates the manager's entrenchment behaviour. The study also revealed that Tobin's Q increases with an increase in ownership of management to $5 \%$ and decreases as ownership increases to $25 \%$. The rising trend continues when ownership is more than $25 \%$. This non-linear relationship is supported by Kowalewski et al. (2010), but only with accounting-based performance indicators (i.e., ROE and ROA). Ownership concentration positively affects ROE when it is lesser than $40 \%$, and negatively affects ROE when the concentration level is $40 \%$ and above.

In another study, De Miguel et al. (2004) provided the evidence that the relationship between family ownership and firm value is positive when family ownership increases up to $35 \%$; it decreases with an increase of ownership from $35 \%$ to $70 \%$; and when the latter increases to over $70 \%$, the relationship again turns positive. Therefore, on the basis of these studies, the following hypothesis is formulated:

$\mathrm{H}_{1}$ There is a non-linear relationship between family ownership and firm value.

\section{RESEARCH MODELS AND MEASUREMENTS}

In this study, we utilised cross-sectional time-series analyses to test our hypothesised non-linear relationship between family ownership and firm value. From 75 nonfinancial public firms listed on the Saudi Stock Exchange (namely Tadawul) in Saudi Arabia over the period from 2007 to 2011 (375 firm-year observations), we developed the following model: $\mathrm{MBV}=\alpha_{0}+\beta_{1}$ famcon $_{i t}+\beta_{2}\left(\text { famcon }_{i t}\right)^{2}+\beta_{3} \mathrm{fdebt}_{i t}+$ $\beta_{4}$ fage $_{i t}+\beta_{5}$ fsize $_{i t}+\beta_{6}$ (industry dummies) ${ }_{i t}+\mu_{i}+$ $\varepsilon_{i t}$,

where $\mathrm{MBV}=$ firm performance, measured by Market-toBook value, $\alpha_{0}=$ the constant, famcon $=$ ratio of family ownership to the total firm ownership, famcon ${ }^{2}=$ the quadratic term of family ownership, fdebt $=$ ratio of the book value of long-term debt to total assets, fage $=$ natural $\log$ of the number of years since the firm's inception, fsize $=$ natural log of the book value of total assets, industry dummies includes eight dummies that are: PET $=$ Petrochemical sector, $\mathrm{CEM}=$ Cement sector, $\mathrm{RET}=$ Retail sector, $\mathrm{FOD}=$ Agricultural and food sector, $\mathrm{INV}=$ Multiinvestment sector, IND = Industrial investment sector, $\mathrm{BLD}=$ Building and construction sector, $\mathrm{EST}=$ Real estate development sector, $\mu_{i}=$ unobserved firm-level random effect, $\varepsilon_{i t}=$ idiosyncratic error. 
In measuring the MBV, the market value of a company is measured by the year-end closing share price multiplied by the number of shares (Beiner, Drobetz, Schmid \& Zimmermann 2006; Yeh 2005; Yurtoglu 2000). Family ownership is measured as the proportion of shares (direct and indirect shareholding) held by the family members over the total number of shares issued (Anderson \& Reeb 2003; Kowalewski et al. 2010; Sacristan-Navarro, Gomez-Anson \& Cabeza-Garcia 2011; Wang 2006). As this study focuses on the non-linearity of the relationship between family ownership and firm performance and more specifically on the quadratic-relationship, a quadratic term of family ownership will be included into the model. According to Al-Dubai, Ku Ismail and Amran (2014a), there is no specific concern on the family ownership cutoff that must be adopted by researchers in order to identify family businesses; it is merely a matter of researchers' convenience. Therefore, a firm is considered as family firm if the family shareholders own at least $5 \%$ of the firm's outstanding shares and at least one member of the controlling family is involved either on the board of directors as chairman/director or in the management as CEO/executive (Al-Dubai et al. 2014a, 2014b). As firm performance may be affected by firm characteristics (Anderson \& Reeb 2003; Sacristan-Navarro et al. 2011), we followed the suggestion of previous studies in family business to control for firm debt, firm age, firm size and industry sectors. Firm debt is a ratio of the book value of long-term debt to total assets (Anderson \& Reeb 2003; Martinez, Stohr \& Quiroga 2007). We measured firm age and firm size as the natural log of the number of years since the firm's inception (Anderson \& Reeb 2003; Arosa et al. 2010; Martinez et al. 2007; Sacristan-Navarro et al. 2011) and the natural log of the book value of total assets (Wang 2006), respectively. However, to control for industry sectors, eight dummy variables were introduced to represent the following eight industrial categories - petrochemical, cement, retail, agriculture and food, multi-investment, industrial investment, building and construction, real estate development. Companies that do not fall under any of these sectors are categorised as others. The dummies used are one less than the number of categories (Arosa et al. 2010).

The descriptive statistics of all variables and distribution of firms according to sectors as well as family and non-family are shown in Table 1. It is observed that there are significant differences between family and nonfamily firms for MBV, firm debt, firm age, and firm size. Family firms are significantly smaller, older and higher in debt financing than their non-family counterparts. With respect to firm value, non-family firms tend to perform better than family firms.

TABLE 1. Summary statistics for the full sample

\begin{tabular}{|c|c|c|c|c|c|c|c|c|c|c|c|c|}
\hline & \multicolumn{5}{|c|}{ All Firms $(n=375)$} & \multicolumn{3}{|c|}{ Family Firms $(n=212)$} & \multicolumn{4}{|c|}{ Non-Family Firms $(n=163)$} \\
\hline & Freq. & $\%$ & Mean & Median & Std. Dev. & Freq. & $\%$ & Mean & Freq. & $\%$ & Mean & t-statistics \\
\hline MBV & & & 1.78 & 1.40 & 1.18 & & & 1.66 & & & 1.95 & $2.38 * *$ \\
\hline Famcon & & & 0.13 & 0.07 & 0.18 & & & - & & & - & - \\
\hline Fdebt & & & 0.14 & 0.08 & 0.15 & & & 0.15 & & & 0.12 & $-2.22 * *$ \\
\hline Fage & & & 24.41 & 23.00 & 12.53 & & & 26.67 & & & 21.48 & $-4.05 * * *$ \\
\hline Fsize & & & 10,000 & 1,800 & 39,000 & & & 3,900 & & & 19,000 & $3.71 * * *$ \\
\hline PET & 55 & 14.70 & & & & 29 & 52.73 & & 26 & 47.27 & & \\
\hline FOD & 55 & 14.70 & & & & 31 & 56.36 & & 24 & 43.64 & & \\
\hline IND & 50 & 13.30 & & & & 20 & 40.00 & & 30 & 60.00 & & \\
\hline BLD & 50 & 13.30 & & & & 39 & 78.00 & & 11 & 22.00 & & \\
\hline CEM & 40 & 10.70 & & & & 25 & 62.50 & & 15 & 37.50 & & \\
\hline RET & 25 & 6.70 & & & & 18 & 72.00 & & 7 & 28.00 & & \\
\hline INV & 25 & 6.70 & & & & 16 & 64.00 & & 9 & 36.00 & & \\
\hline EST & 25 & 6.70 & & & & 9 & 36.00 & & 16 & 64.00 & & \\
\hline \multirow[t]{2}{*}{ Others } & 50 & 13.30 & & & & 25 & 50.00 & & 25 & 50.00 & & \\
\hline & 375 & 100.00 & & & & 212 & 56.53 & & 163 & 43.47 & & \\
\hline
\end{tabular}

Note: $\mathrm{MBV}=$ Market-to-Book value ratio, Famcon = Family ownership, Fdebt $=$ Firm debt, Fage $=$ Firm age, Fsize $=$ Firm size is total assets expressed in millions of Saudi Riyals, $\mathrm{PET}=$ Petrochemical sector, $\mathrm{FOD}=$ Agricultural and food sector, $\mathrm{IND}=$ Industrial investment sector, $\mathrm{BLD}=\mathrm{Building}$ and construction sector, $\mathrm{CEM}=\mathrm{Cement}$ sector, $\mathrm{RET}=$ Retail sector, INV $=$ Multi-investment sector, \& EST $=$ Real estate development sector. $* \mathrm{p}<0.10, * * \mathrm{p}<0.05, * * \mathrm{p}<0.01$

\section{ANALYSIS AND RESULTS}

In the model estimation, multicollinearity, autocorrelation and heteroscedasticity were examined. The Pearson correlation is displayed in Table 2. According to the results, Famcon has no significant correlation with performance indicator (MBV). Meanwhile, Fdebt and Fsize have small and medium negative correlations with MBV, respectively; 
and Fage has a small but positive correlation. Additionally, it is proven that multicollinearity is not a cause of concern, whereby the highest observed variance inflation index (VIF) is 2.11, which is far below the suggested value by Hair, Black, Babin and Anderson (2010). To examine our data for heteroscedasticity problem, the Breusch-Pagan/ Cook-Weisberg test was employed. It was found that our models reject the null hypothesis $\left(\mathrm{Chi}^{2}=5.17, P<0.05\right)$, which indicates that the residuals are heteroscedastic. Following Wooldridge's (2002) procedure, a Wald test using (xtserial) written-command was performed in order to test for the existence of autocorrelation. The null hypothesis of no autocorrelation was rejected $(\mathrm{F}=12.746, P<0.01)$, suggesting that autocorrelation exists. Therefore, Feasible Generalized Least Squares (FGLS) random-effects model was used and robust by controlling for heteroscedasticity and autocorrelation using panels(het) and corr(arl) options in STATA 12.0, respectively.

TABLE 2. Correlations among variables

\begin{tabular}{lcccccc}
\hline & MBV & Famcon & Fdebt & Fage & Fsize & VIF \\
\hline MBV & 1.00 & & & & & \\
Famcon & 0.00 & 1.00 & & & & 1.11 \\
Fdebt & $-0.22 * * *$ & -0.05 & 1.00 & & & 2.11 \\
Fage & $0.12 * *$ & 0.03 & $-0.21^{* * *}$ & 1.00 & & 1.33 \\
Fsize & $-0.39 * * *$ & -0.04 & $0.58^{* * *}$ & $-0.13 * *$ & 1.00 & 1.99 \\
\hline Note: & $* * *$ significant at $1 \%$ level $(2$ tailed), **significant at $5 \%$ level (2 tailed), *significant at $10 \%$ \\
& level (2 tailed). MBV = Market-to-Book value ratio, Famcon = A ratio of family-owned shares \\
to the total firm's shares, Fdebt = A ratio of the book value of long-term debt to total assets, Fage \\
$\quad$ Natural log of the number of years since the firm's inception, Fsize = Natural log of the book \\
value of total assets.
\end{tabular}

Table 3 is divided into three panels $-\mathrm{A}, \mathrm{B}$, and $\mathrm{C}$, and each panel includes two models: one for testing a direct relationship between family ownership and firm value and the other for testing our hypothesis on the non-linearity of the relationship. Panels A, B and C represent different family firm definitions with different ownership cut-offs (i.e., $5 \%, 10 \%$ and $20 \%$ ).

From our main model (Model 2) of Panel A in Table 3, the results show that the coefficient of family ownership variable (Famcon) is negative $(\beta=-2.89)$, and its quadratic term Famcon 2 is positive $(\beta=5.09)$, both are strongly significant at the $1 \%$ level. This suggests that family ownership-firm value relationship is non-linear U-shaped. The fact that the relationship is quadratic strongly supports our hypothesis on the relationship between family ownership and firm value. However, the result is contrary to the inverted U-shaped relationship found by Anderson and Reeb (2003), De Miguel et al. (2004) and Kowalewski et al. (2010) for the US, Spain and Polish companies, respectively.

The U-shaped relationship indicates that family shareholders expropriate their minority shareholders from the lowest level of family ownership up to a certain degree of family ownership, where the conflict of interest between family owners and minority shareholders is low. After reaching a certain level of ownership, the relationship reverses, in which firm performance increases as family ownership increases. In determining the turning point of the curve, we followed De Miguel et al.'s (2004) method, whereby ownership turning point $=-\left(\beta_{1} / 2 \beta_{2}\right)$. Thus, family ownership turning point is $-(-2.89 / 2 * 5.09)=0.28$. The result suggests that as family ownership increases from $0 \%$ to $28 \%$, the Saudi firms' value decreases. This implies that family shareholders are getting more expropriating when the ownership increases from $0 \%$ to $28 \%$. Beyond this point (28\%), any increment to family ownership results in an increase in firm value. As family ownership increases from $28 \%$ onwards, family members tend to display extensive controlling behaviour; their private advantages and objectives converge with that of the firm.

A possible explanation is that when family ownership is very small and starts to increase, they tend to focus on satisfying their personal objectives and enjoy greater private benefits at the expense of minority shareholders. Nevertheless, when families own about one third of the firm's shareholding, they feel that their objectives have been satisfied, which subsequently mitigates the conflicts between them and their minority shareholders. To say this differently, any increase in family ownership in Saudi firms creates greater perception among family owners that the firm's value is closely tied to family wealth. This motivates family members to improve firm value so as to safeguard their family's name and reputation, which are of major concerns to them.

In order to check for the robustness of our results, we redefined family firms by adopting different family ownership percentages: $10 \%$ and 20\% (Panels B and C in Table 3, respectively). As can be seen from the table, family ownership variable (Famcon) and its quadratic term $\left(\right.$ Famcon $\left.^{2}\right)$ keep their signs and remain significant. These results confirmed the argument made by Al-Dubai et al. (2014a) that adopting different family ownership cut-offs in defining family firms has no effect on the findings of the relationship between family ownership and firm performance. 
TABLE 3. Results of cross-sectional time-series analyses

\begin{tabular}{|c|c|c|c|c|c|c|}
\hline \multirow[b]{2}{*}{ Variables } & \multicolumn{2}{|c|}{$\begin{array}{c}\text { Panel A: Family } \\
\text { Ownership 5\% }\end{array}$} & \multicolumn{2}{|c|}{$\begin{array}{l}\text { Panel B: Family } \\
\text { Ownership } 10 \%\end{array}$} & \multicolumn{2}{|c|}{$\begin{array}{l}\text { Panel C: Family } \\
\text { Ownership 20\% }\end{array}$} \\
\hline & Model (1) & Model (2) & Model (3) & Model (4) & Model (5) & Model (6) \\
\hline Constant & $\begin{array}{c}7.46 * * * \\
(9.22)\end{array}$ & $\begin{array}{c}7.16^{* * *} \\
(9.75)\end{array}$ & $\begin{array}{c}7.46^{* * *} \\
(9.18)\end{array}$ & $\begin{array}{c}7.13 * * * \\
(9.35)\end{array}$ & $\begin{array}{l}7.40 * * * \\
(8.94)\end{array}$ & $\begin{array}{c}7.18 * * * \\
(8.87)\end{array}$ \\
\hline Famcon & $\begin{array}{c}0.08 \\
(0.31)\end{array}$ & $\begin{array}{c}-2.89 * * * \\
(-4.46)\end{array}$ & $\begin{array}{c}0.10 \\
(0.42)\end{array}$ & $\begin{array}{c}-2.40 * * * \\
(-3.84)\end{array}$ & $\begin{array}{c}0.30 \\
(1.30)\end{array}$ & $\begin{array}{l}-1.10^{*} \\
(-1.66)\end{array}$ \\
\hline Famcon2 & & $\begin{array}{c}5.09 * * * \\
(4.53)\end{array}$ & & $\begin{array}{c}4.43 * * * \\
(4.00)\end{array}$ & & $\begin{array}{c}2.52 * * \\
(2.12)\end{array}$ \\
\hline Fdebt & $\begin{array}{c}0.07 \\
(0.23)\end{array}$ & $\begin{array}{c}0.21 \\
(0.82)\end{array}$ & $\begin{array}{c}0.07 \\
(0.24)\end{array}$ & $\begin{array}{c}0.29 \\
(1.13)\end{array}$ & $\begin{array}{c}0.13 \\
(0.41)\end{array}$ & $\begin{array}{l}0.16 \\
(0.54)\end{array}$ \\
\hline Fage & $\begin{array}{l}-0.15 * * \\
(-2.51)\end{array}$ & $\begin{array}{l}-0.02 \\
(-0.32)\end{array}$ & $\begin{array}{l}-0.15 * * \\
(-2.50)\end{array}$ & $\begin{array}{c}-0.04 \\
(-0.74)\end{array}$ & $\begin{array}{l}-0.14 * * \\
(-2.33)\end{array}$ & $\begin{array}{l}-0.10^{*} \\
(-1.68)\end{array}$ \\
\hline Fsize & $\begin{array}{c}-0.26 * * * \\
(-7.11)\end{array}$ & $\begin{array}{c}-0.27 * * * \\
(-8.07)\end{array}$ & $\begin{array}{c}-0.26 * * * \\
(-7.07)\end{array}$ & $\begin{array}{c}-0.26 * * * \\
(-7.73)\end{array}$ & $\begin{array}{c}-0.26 * * * \\
(-6.93)\end{array}$ & $\begin{array}{c}-0.26 * * * \\
(-7.01)\end{array}$ \\
\hline Industry dummies & Included & Included & Included & Included & Included & Included \\
\hline$N$ & 375 & 375 & 375 & 375 & 375 & 375 \\
\hline$R^{2}$ & 0.25 & 0.28 & 0.25 & 0.27 & 0.25 & 0.26 \\
\hline Wald chi ${ }^{2}$ & 130.66 & 159.37 & 128.88 & 149.02 & 125.93 & 129.11 \\
\hline Prob $>F$ & 0.00 & 0.00 & 0.00 & 0.00 & 0.00 & 0.00 \\
\hline
\end{tabular}

Note: Figure in the parenthesis is (z value), ***significant at $1 \%$ level (2 tailed), **significant at 5\% level (2 tailed), *significant at $10 \%$ level ( 2 tailed). Famcon $=$ A ratio of family-owned shares to the total firm's shares, Famcon $2=$ the quadratic term of family ownership, Fdebt $=$ A ratio of the book value of long-term debt to total assets, Fage $=$ Natural log of the number of years since the firm's inception, Fsize $=$ Natural log of the book value of total assets, Industry dummies includes eight dummies represents the nine industry sectors that are petrochemical, cement, retail, agriculture and food, multi-investment, industrial investment, building and construction, real estate development.

We also checked for the robustness of our results by conducting a cross-sectional year-by-year analysis separately (Table 4) in order to confirm the presence of the U-shaped relationship. We noticed that the U-shaped relationship between family ownership (Famcon2) and firm value (MBV) is insignificant for year 2007; however, it is significant for the four subsequent years $(2008-2011)$.

TABLE 4. Results of cross-sectional analyses

\begin{tabular}{|c|c|c|c|c|c|c|c|c|c|c|}
\hline \multirow[b]{2}{*}{ Variables } & \multicolumn{9}{|c|}{ MBV } & \multirow[b]{2}{*}{2011} \\
\hline & 2007 & 2007 & 2008 & 2008 & 2009 & 2009 & 2010 & 2010 & 2011 & \\
\hline Constant & $\begin{array}{c}14.76^{* * * *} \\
(5.25)\end{array}$ & $\begin{array}{c}14.36^{* * *} \\
(5.04)\end{array}$ & $\begin{array}{c}3.30 * * * \\
(2.79)\end{array}$ & $\begin{array}{c}2.92 * * \\
(2.45)\end{array}$ & $\begin{array}{c}8.18 * * * \\
(3.51)\end{array}$ & $\begin{array}{c}7.98 * * * \\
(3.52)\end{array}$ & $\begin{array}{c}4.72 * * \\
(2.30)\end{array}$ & $\begin{array}{c}4.60^{* *} \\
(2.37)\end{array}$ & $\begin{array}{c}8.46^{* * * *} \\
(3.65)\end{array}$ & $\begin{array}{c}8.09 * * * \\
(3.70)\end{array}$ \\
\hline Famcon & $\begin{array}{c}0.66 \\
(1.23)\end{array}$ & $\begin{array}{c}-2.54 \\
(-1.03)\end{array}$ & $\begin{array}{l}1.34 * * \\
(2.56)\end{array}$ & $\begin{array}{c}-1.73 \\
(-1.63)\end{array}$ & $\begin{array}{c}0.30 \\
(0.53)\end{array}$ & $\begin{array}{c}-4.03 * * \\
(-2.18)\end{array}$ & $\begin{array}{c}0.09 \\
(0.16)\end{array}$ & $\begin{array}{c}-5.15 * * \\
(-2.58)\end{array}$ & $\begin{array}{c}-0.48 \\
(-0.70)\end{array}$ & $\begin{array}{c}-5.27 * * * \\
(-2.95)\end{array}$ \\
\hline Famcon2 & & $\begin{array}{c}5.61 \\
(1.42)\end{array}$ & & $\begin{array}{c}5.38 * * \\
(2.49)\end{array}$ & & $\begin{array}{l}7.61 * * \\
(2.51)\end{array}$ & & $\begin{array}{c}9.25 * * * \\
(2.80)\end{array}$ & & $\begin{array}{c}8.54 * * * \\
(2.78)\end{array}$ \\
\hline Fdebt & $\begin{array}{c}-1.03 \\
(-0.62)\end{array}$ & $\begin{array}{c}-0.32 \\
(-0.21)\end{array}$ & $\begin{array}{c}0.63 \\
(0.73)\end{array}$ & $\begin{array}{c}1.18 \\
(1.39)\end{array}$ & $\begin{array}{c}0.23 \\
(0.21)\end{array}$ & $\begin{array}{c}0.98 \\
(0.92)\end{array}$ & $\begin{array}{c}-0.28 \\
(-0.22)\end{array}$ & $\begin{array}{c}0.67 \\
(0.55)\end{array}$ & $\begin{array}{c}-0.46 \\
(-0.39)\end{array}$ & $\begin{array}{c}0.05 \\
(0.04)\end{array}$ \\
\hline Fage & $\begin{array}{c}0.20 \\
(1.17)\end{array}$ & $\begin{array}{c}0.23 \\
(1.34)\end{array}$ & $\begin{array}{c}0.05 \\
(0.43)\end{array}$ & $\begin{array}{c}0.13 \\
(1.10)\end{array}$ & $\begin{array}{c}0.16 \\
(1.10)\end{array}$ & $\begin{array}{l}0.30 * \\
(1.86)\end{array}$ & $\begin{array}{c}0.28 \\
(1.48)\end{array}$ & $\begin{array}{c}0.47 * * \\
(2.24)\end{array}$ & $\begin{array}{c}0.21 \\
(1.07)\end{array}$ & $\begin{array}{l}0.40^{*} \\
(1.86)\end{array}$ \\
\hline Fsize & $\begin{array}{c}-0.61 * * * \\
(-4.61)\end{array}$ & $\begin{array}{c}-0.60 * * * \\
(-4.49)\end{array}$ & $\begin{array}{c}-0.13^{* *} \\
(-2.55)\end{array}$ & $\begin{array}{c}-0.12 * * \\
(-2.46)\end{array}$ & $\begin{array}{c}-0.34 * * * \\
(-3.24)\end{array}$ & $\begin{array}{c}-0.35 * * * \\
(-3.43)\end{array}$ & $\begin{array}{c}-0.21 * * \\
(-2.19)\end{array}$ & $\begin{array}{c}-0.23 * * \\
(-2.53)\end{array}$ & $\begin{array}{c}-0.35 * * * \\
(-3.22)\end{array}$ & $\begin{array}{c}-0.36 * * * \\
(-3.53)\end{array}$ \\
\hline Industry dummies & Included & Included & Included & Included & Included & Included & Included & Included & Included & Included \\
\hline $\mathrm{N}$ & 75 & 75 & 75 & 75 & 75 & 75 & 75 & 75 & 75 & 75 \\
\hline $\mathrm{R}^{2}$ & 0.42 & 0.43 & 0.37 & 0.43 & 0.36 & 0.42 & 0.31 & 0.39 & 0.44 & 0.50 \\
\hline $\mathrm{F}$ & 4.89 & 5.15 & 5.02 & 6.28 & 3.41 & 3.47 & 3.54 & 3.50 & 4.10 & 3.94 \\
\hline Prob $>$ F & 0.00 & 0.00 & 00 & 0.00 & 0.00 & 0.00 & 0.00 & 0.00 & 0.00 & 0.00 \\
\hline
\end{tabular}

Note: Figure in the parenthesis is ( $t$ value), ***significant at $1 \%$ level (2 tailed), **significant at $5 \%$ level $(2$ tailed $)$, $*$ significant at $10 \%$ level $(2$ tailed). Famcon $=$ A ratio of family-owned shares to the total firm's shares, Famcon $2=$ the quadratic term of family ownership, Fdebt $=$ A ratio of the book value of long-term debt to total assets, Fage $=$ Natural log of the number of years since the firm's inception, Fsize $=$ Natural log of the book value of total assets, Industry dummies includes eight dummies represents the nine industry sectors that are petrochemical, cement, retail, agriculture and food, multi-investment, industrial investment, building and construction, real estate development. 
Further, we excluded non-family businesses from the analyses, focusing only on family businesses with the different percentages $(5 \%, 10 \%$ and $20 \%)$. Table 5 shows that the non-linear U-shaped relationship between family ownership and MBV is significant with the lower ownership percentages (i.e., 5\% and 10\%). However, with the $20 \%$ family ownership, the relationship becomes inverted U-shaped but not significant at any level of significance.
In general, we provided sufficient evidence for the non-linear relationship between the aforementioned variables in the analyses on the expropriated-monitoring behaviour of Saudi families in their businesses. Further, it suggests that researchers need to examine such nonlinearity between family ownership and accounting performance in order to provide an accurate conclusion on family ownership's impact.

TABLE 5. Cross-sectional time-series analyses for only family businesses

\begin{tabular}{|c|c|c|c|c|c|c|}
\hline \multirow[b]{2}{*}{ Variables } & \multicolumn{2}{|c|}{ 5\% Family Ownership } & \multicolumn{2}{|c|}{ 10\% Family Ownership } & \multicolumn{2}{|c|}{$20 \%$ Family Ownership } \\
\hline & Model (1) & Model (2) & Model (3) & Model (4) & Model (5) & Model (6) \\
\hline Constant & $\begin{array}{c}5.805 * * * \\
(4.68)\end{array}$ & $\begin{array}{c}6.248 * * * \\
(5.19)\end{array}$ & $\begin{array}{c}6.533 * * * \\
(4.94)\end{array}$ & $\begin{array}{c}5.622 * * * \\
(7.21)\end{array}$ & $\begin{array}{l}2.534 \\
(1.09)\end{array}$ & $\begin{array}{l}2.532 \\
(0.98)\end{array}$ \\
\hline Famcon & $\begin{array}{l}0.217 \\
(0.62)\end{array}$ & $\begin{array}{c}-3.923 * * * \\
(-2.83)\end{array}$ & $\begin{array}{l}0.274 \\
(0.71)\end{array}$ & $\begin{array}{c}-2.775 * * \\
(-2.19)\end{array}$ & $\begin{array}{c}1.406 * * \\
(2.13)\end{array}$ & $\begin{array}{l}2.107 \\
(0.56)\end{array}$ \\
\hline Famcon2 & & $\begin{array}{c}6.063 * * * \\
(2.98)\end{array}$ & & $\begin{array}{c}4.807 * * * \\
(2.61)\end{array}$ & & $\begin{array}{l}-0.981 \\
(-0.21)\end{array}$ \\
\hline Fdebt & $\begin{array}{l}0.388 \\
(1.19)\end{array}$ & $\begin{array}{l}0.525 \\
(1.42)\end{array}$ & $\begin{array}{l}0.326 \\
(0.81)\end{array}$ & $\begin{array}{c}1.284 * * * \\
(3.51)\end{array}$ & $\begin{array}{c}0.824 * \\
(1.75)\end{array}$ & $\begin{array}{l}0.776 \\
(1.51)\end{array}$ \\
\hline Fage & $\begin{array}{c}-0.264 * * * \\
(-2.76)\end{array}$ & $\begin{array}{l}-0.144 \\
(-1.39)\end{array}$ & $\begin{array}{c}-0.337 * * * \\
(-2.83)\end{array}$ & $\begin{array}{l}-0.121 \\
(-1.33)\end{array}$ & $\begin{array}{c}-0.0634 \\
(-0.45)\end{array}$ & $\begin{array}{l}-0.103 \\
(-0.55)\end{array}$ \\
\hline Fsize & $\begin{array}{c}-0.179 * * * \\
(-2.77)\end{array}$ & $\begin{array}{c}-0.196^{* * *} \\
(-3.11)\end{array}$ & $\begin{array}{c}-0.201 * * * \\
(-3.05)\end{array}$ & $\begin{array}{c}-0.184 * * * \\
(-4.57)\end{array}$ & $\begin{array}{c}-0.0762 \\
(-0.78)\end{array}$ & $\begin{array}{c}-0.0745 \\
(-0.70)\end{array}$ \\
\hline Industry Dummies & Included & Included & Included & Included & Included & Included \\
\hline$N$ & 208 & 208 & 160 & 160 & 84 & 84 \\
\hline$R^{2}$ & 0.1999 & 0.2192 & 0.2358 & 0.2420 & 0.2354 & 0.2254 \\
\hline Wald $c h i^{2}$ & 92.02 & 113.23 & 86.58 & 215.47 & 99.34 & 94.49 \\
\hline Prob $>F$ & 0.00 & 0.00 & 0.00 & 0.00 & 0.00 & 0.00 \\
\hline
\end{tabular}

Note: Figure in the parenthesis is (z value), ***significant at $1 \%$ level ( 2 tailed), **significant at $5 \%$ level ( 2 tailed), *significant at $10 \%$ level ( 2 tailed). Famcon $=$ A ratio of family-owned shares to the total firm's shares, Famcon $2=$ the quadratic term of family ownership, Fdebt $=$ A ratio of the book value of long-term debt to total assets, Fage $=$ Natural $\log$ of the number of years since the firm's inception, Fsize $=$ Natural log of the book value of total assets, Industry dummies includes eight dummies represents the nine industry sectors that are petrochemical, cement, retail, agriculture and food, multi-investment, industrial investment, building and construction, real estate development.

\section{CONCLUSION}

Even though family ownership on firm performance has been extensively examined, the examination has been limited to the direct effect. A few studies have however tackled the possibility of the non-linear relationship between the aforementioned variables. Thus, the main contribution of this study is to provide new evidence from the context of the Arabic region on how families' behaviour changes from time to time, which result in good and bad market performance.

From a sample of 75 non-financial public listed companies in Tadawul and for five consecutive years from 2007 until 2011 (375 firm-year observations), we examined the non-linear relationship between family ownership and firm value as measured by MBV in order to investigate the behaviour of Saudi families in their businesses. Consistent with some previous studies, we found that the behaviour of the Saudi families is changeable during the life of the business, depending on the level of their ownership in the firms. Clearly, families start to expropriate their minority shareholders initially, and after certain degree of ownership (28\%), they have greater incentives to converge their private advantages and objectives with those of the firm, consequently increasing its value. We sought to make sure that our results are robust with respect to different family definitions and analyses. We found that our findings are robust and suggested that researchers need to be more cautious of the non-linearity of the relationship. All in all, our findings indicated that the good and bad points about having family ownership would depend on their level of ownership. This study showed that at about $28 \%$ family ownership, companies are at their worst point in terms of MBV. A significantly lower and higher family ownership percentage is likely to improve firm value.

In terms of the implication of this study, the results offered suggestions to the practitioners (e.g., leaders and 
policy makers) in Saudi Arabia, such as the Capital Market Authority (CMA) and Saudi Arabian Monetary Agency (SAMA) to revise the existing corporate governance rules. While the existing rules require public listed companies to disclose management and board members' ownership, the ownership percentages and identity of the remaining owners (family or non-family) need not be disclosed. This information has significant effects on investors' decisionmaking and may be used as a reference for the investors to select the appropriate firm for their investments. Thus, leaders and policy makers are highly encouraged to introduce new rules that mandate public listed companies to disclose, in their corporate governance reports, such information.

The limitation of our study is that we only focused on the quadratic relationship between family ownership and firm value as evidence of non-linearity. Hence, future studies are encouraged to examine the other types of nonlinearity, such as the cubic relationship. Another limitation is the adoption of different family ownership percentages in our robustness analyses. Future studies may consider adopting different family definition categories (e.g., family management, family control and family succession).

The results suggested that there may be a need to encourage policy makers in Saudi Arabia to impose the full disclosure of firms' ownership information, including the percentage of family ownership and the identity of the owners.

\section{REFERENCES}

Abdullah, F., Shah, A., Iqbal, A.M. \& Gohar, R. 2011. The effect of group and family ownership on firm performance: Empirical evidence from Pakistan. International Review of Business Research Papers 7(4): 177-194.

Al-Dubai, S.A.A., Ku Ismail, N.I.K. \& Amran, N.A. 2014a. Family business definition: A matter of concern or a matter of convenience? Corporate Ownership \& Control 11(2): 274-280.

Al-Dubai, S.A.A., Ku Ismail, N.I.K. \& Amran, N.A. 2014b. Family involvement in ownership, management, and firm performance: Moderating and Direct-Effect Models. Asian Social Science 10(14): 193-205.

Amran, N.A. \& Ahmad, A.C. 2010. Family succession and firm performance among Malaysian Companies. International Journal of Business and Social Science 1(2): 193-203.

Anderson, R.C. \& Reeb, D.M. 2003. Founding-family ownership and firm performance: Evidence from the S\&P 500. Journal of Finance 58(3): 1301-1328.

Arosa, B., Iturralde, T. \& Maseda, A. 2010. Outsiders on the board of directors and firm performance: Evidence from Spanish non-listed family firms. Journal of Family Business Strategy 1(4): 236-245.

Barontini, R. \& Caprio, L. 2006. The effect of family control on firm value and performance: Evidence from Continental Europe. European Financial Management 12(5): 689723.

Beiner, S., Drobetz, W., Schmid, M.M. \& Zimmermann, H. 2006. An integrated framework of Corporate Governance and Firm Valuation. European Financial Management 12(2): 249-283.
Ben-Amar, W. \& Andre, P. 2006. Separation of ownership from control and acquiring firm performance: The case of family ownership in Canada. Journal of Business Finance \& Accounting 33(3-4): 517-543.

Claessens, S., Djankov, S. \& Lang, L.H.P. 2000. The separation of ownership and control in East Asian Corporations. Journal of Financial Economics 58(1-2): 81-112.

Corbetta, G. \& Salvato, C. 2004. Self-serving or self-actualizing? Models of man and agency costs in different types of family firms: A commentary on "Comparing the agency costs of family and non-family firms: Conceptual issues and exploratory evidence." Entrepreneurship Theory and Practice 28(4): 355-362.

De Miguel, A., Pindado, J. \& De la Torre, C. 2004. Ownership structure and firm value: New evidence from Spain. Strategic Management Journal 25(12): 1199-1207.

Hair, J.F., Black, W.C., Babin, B.J. \& Anderson, R.E. 2010. Multivariate Data Analysis. $7^{\text {th }}$ edition. Upper Saddle River, NJ: Prentice Hall.

Jensen, M.C. \& Meckling, W.H. 1976. Theory of the firm: Managerial behavior, agency costs and ownership structure. Journal of Financial Economics 3(4): 305-360.

Kowalewski, O., Talavera, O. \& Stetsyuk, I. 2010. Influence of family involvement in management and ownership on firm performance: Evidence From Poland. Family Business Review 23(1): 45-59.

Kula, V. 2005. The impact of the roles, structure and process of boards on firm performance: Evidence from Turkey. Corporate Governance: An International Review 13(2): 265-276.

La Porta, R., Lopez-de-Silanes, F. \& Shleifer, A. 1999. Corporate ownership around the world. Journal of Finance 54(2): 471-517.

Lee, J. 2006. Family firm performance: Further evidence. Family Business Review 19(2): 103-114.

Martinez, J.I., Stohr, B.S. \& Quiroga, B.F. 2007. Family ownership and firm performance: Evidence from public companies in Chile. Family Business Review 20(2): 8394.

Maury, B. 2006. Family ownership and firm performance: Empirical evidence from Western European corporations. Journal of Corporate Finance 12(2): 321-341.

Miller, D., Le Breton-Miller, I., Lester, R.H. \& Cannella, A.A. 2007. Are family firms really superior performers? Journal of Corporate Finance 13(5): 829-858.

Morck, R., Shleifer, A. \& Vishny, R.W. 1988. Management ownership and market valuation: An empirical analysis. Journal of Financial Economics 20(1-2): 293-315.

Pindado, J. \& Torre, C.D.L. 2006. The role of investment, financing and dividend decisions in explaining corporate ownership structure: Empirical evidence from Spain. European Financial Management 12(5): 661-687.

Sacristan-Navarro, M., Gomez-Anson, S. \& Cabeza-Garcia, L. 2011. Family ownership and control, the presence of other large shareholders, and firm performance: Further evidence. Family Business Review 24(1): 71-93.

Saito, T. 2008. Family firms and firm performance: Evidence from Japan. Journal of the Japanese and International Economies 22(4): 620-646.

Schulze, W.S., Lubatkin, M.H., Dino, R.N. \& Buchholtz, A.K. 2001. Agency relationships in family firms: Theory and evidence. Organization Science 12(2): 99-116. 
Sciascia, S. \& Mazzola, P. 2008. Family involvement in ownership and management: Exploring nonlinear effects on performance. Family Business Review 21(4): 331-345.

Seifert, B., Gonenc, H. \& Wright, J. 2005. The international evidence on performance and equity ownership by insiders, blockholders, and institutions. Journal of Multinational Financial Management 15(2): 171-191.

Villalonga, B. \& Amit, R. 2006. How do family ownership, control and management affect firm value? Journal of Financial Economics 80(2): 385-417.

Wang, D. 2006. Founding family ownership and earnings quality. Journal of Accounting Research 44(3): 619-656.

Wooldridge, J.M. 2002. Econometric Analysis of Cross Section and Panel Data. $2^{\text {nd }}$ edition. Cambridge: Massachusetts Institute of Technology.

Yeh, Y.-H. 2005. Do controlling shareholders enhance corporate value? Corporate Governance: An International Review 13(2): 313-325.

Yurtoglu, B.B. 2000. Ownership, control and performance of Turkish listed firms. Empirica 27(2): 193-222.

Shehabaddin Abdullah A. Al-Dubai (corresponding author)

School of Accountancy

UUM College of Business

Universiti Utara Malaysia

06010 UUM Sintok, Kedah, MALAYSIA.

E-Mail: shehabaddin@uum.edu.my

Ku Nor Izah Ku Ismail

School of Accountancy

UUM College of Business

Universiti Utara Malaysia

06010 uUm Sintok, Kedah, MALAYSIA.

E-Mail: norizah@uum.edu.my

Noor Afza Amran

School of Accountancy

UUM College of Business

Universiti Utara Malaysia

06010 UUM Sintok, Kedah, MALAYSIA.

E-Mail: afza@uum.edu.my 
